\title{
Clostridium ganghwense sp. nov., isolated from tidal flat sediment
}

\author{
Seil Kim, Hyunyoung Jeong, Sanggoo Kim and Jongsik Chun \\ School of Biological Sciences and Institute of Microbiology, Seoul National University, 56-1 \\ Shillim-dong, Kwanak-gu, Seoul 151-742, Republic of Korea
}

Correspondence

Jongsik Chun

jchun@snu.ac.kr

\begin{abstract}
A Gram-negative, strictly anaerobic, halophilic, motile, sporulating and rod-shaped bacterium, designated strain $\mathrm{HY}-42-06^{\top}$, was isolated from tidal flat sediment from Ganghwa Island in South Korea. The isolate produced glycerol, ethanol and $\mathrm{CO}_{2}$ as fermentation end-products from glucose. Strain $\mathrm{HY}-42-06^{\top}$ grew optimally at $35^{\circ} \mathrm{C}, \mathrm{pH} 7 \cdot 5$ and $3 \%(\mathrm{w} / \mathrm{v})$ artificial sea salts. No growth was observed in the absence of sea salts. In phylogenetic analyses based on 16S rRNA gene sequence, strain $\mathrm{HY}-42-06^{\top}$ showed a distinct phyletic line within the members of cluster I of the order Clostridiales. The closest phylogenetic neighbour to strain $\mathrm{HY}-42-06^{\top}$ was Clostridium novyi ATCC $17861^{\top}$ (94.91\% 16S rRNA gene sequence similarity). Several phenotypic characters readily differentiate the tidal flat isolate from phylogenetically related clostridia. On the basis of polyphasic evidence, strain $\mathrm{HY}-42-06^{\top}$ should be classified as a representative of a novel species, for which the name Clostridium ganghwense sp. nov. is proposed. The type strain is $\mathrm{HY}-42-06^{\top}$ $\left(=\right.$ IMSNU $40127^{\top}=$ KCTC $5146^{\top}=$ JCM $\left.13193^{\top}\right)$.
\end{abstract}

The prokaryotic inhabitants of tidal flat sediments in Korea have been shown to be very diverse (Kim et al., 2004) and some of them have been isolated and described as novel species (Yi \& Chun, 2004; Yi et al., 2003). In this study, we report the taxonomic description of a strictly anaerobic bacterium, designated strain HY-42-06 ${ }^{\mathrm{T}}$.

Strain HY-42-06 ${ }^{\mathrm{T}}$ was isolated from a tidal flat sediment sample $\left(37^{\circ} 35 \cdot 319^{\prime} \mathrm{N} 126^{\circ} 27 \cdot 245^{\prime} \mathrm{E}\right)$ from Ganghwa Island, South Korea, using a standard dilution plating method (Jeong et al., 2004). The isolate was recovered and routinely maintained using reinforced Clostridium medium (RCM; Difco) supplemented with $4 \%$ artificial sea salts (Sigma) at $25^{\circ} \mathrm{C}$ under anaerobic conditions.

Bacterial DNA preparation and PCR amplification and sequencing of 16S rRNA genes were carried out as described previously (Chun \& Goodfellow, 1995). The resultant 16S rRNA gene sequence of strain HY- $42-06^{\mathrm{T}}$ was aligned manually against sequences obtained from the GenBank database. Phylogenetic trees were inferred using the Fitch-Margoliash (Fitch \& Margoliash, 1967), maximumlikelihood (Felsenstein, 1993), maximum-parsimony (Fitch,

Published online ahead of print on 18 November 2005 as DOI 10.1099/ijs.0.63791-0.

The GenBank/EMBL/DDBJ accession number for the 16S rRNA gene sequence of strain $\mathrm{HY}-42-06^{\top}$ is AY903294.

Scanning and transmission electron micrographs of cells of strain $\mathrm{HY}$ $42-06^{\top}$ are available as supplementary figures in IJSEM Online.
1971) and neighbour-joining (Saitou \& Nei, 1987) methods. Evolutionary distance matrices were generated according to Jukes \& Cantor (1969). The tree topologies obtained were evaluated by bootstrap analyses (Felsenstein, 1985) of the neighbour-joining method based on 1000 resamplings. The alignment and phylogenetic analysis were carried out using the jPHYDIT program (available at http://chunlab.snu.ac.kr/ jphydit/; Jeon et al., 2005) and PAUP 4.0 (Swofford, 1998) as described by Chun et al. (2000).

A nearly complete $16 \mathrm{~S}$ rRNA gene sequence was obtained for strain HY-42-06 ${ }^{\mathrm{T}}$ (1395 bp) and it was used for an initial BLAST search against the GenBank database. The search result clearly indicated that strain HY- $42-06^{\mathrm{T}}$ belonged to cluster I of the order Clostridiales defined by Collins et al. (1994); this cluster contains the type species of the genus Clostridium, Clostridium butyricum. The newly determined sequence was then manually aligned against those of members of cluster I, based on the secondary structure of bacterial $16 \mathrm{~S}$ rRNA. Phylogenetically, strain HY- $42-06^{\mathrm{T}}$ was most closely related to Clostridium novyi ATCC $17861^{\mathrm{T}}$ (94.91\% 16S rRNA gene sequence similarity), followed by Clostridium haemolyticum DSM $5565^{\mathrm{T}}(94 \cdot 84 \%)$ and Clostridium homopropionicum DSM $5847^{\mathrm{T}}(94 \cdot 81 \%)$. These levels of $16 \mathrm{~S}$ rRNA gene sequence similarity clearly suggest that strain HY- $42-06^{\mathrm{T}}$ represents a novel species in the genus Clostridium. Phylogenetic analysis, based on four different tree-making algorithms, also supported this conclusion, as strain HY-42-06 ${ }^{\mathrm{T}}$ formed an independent phyletic line within the Clostridium cluster I clade (Fig. 1). 


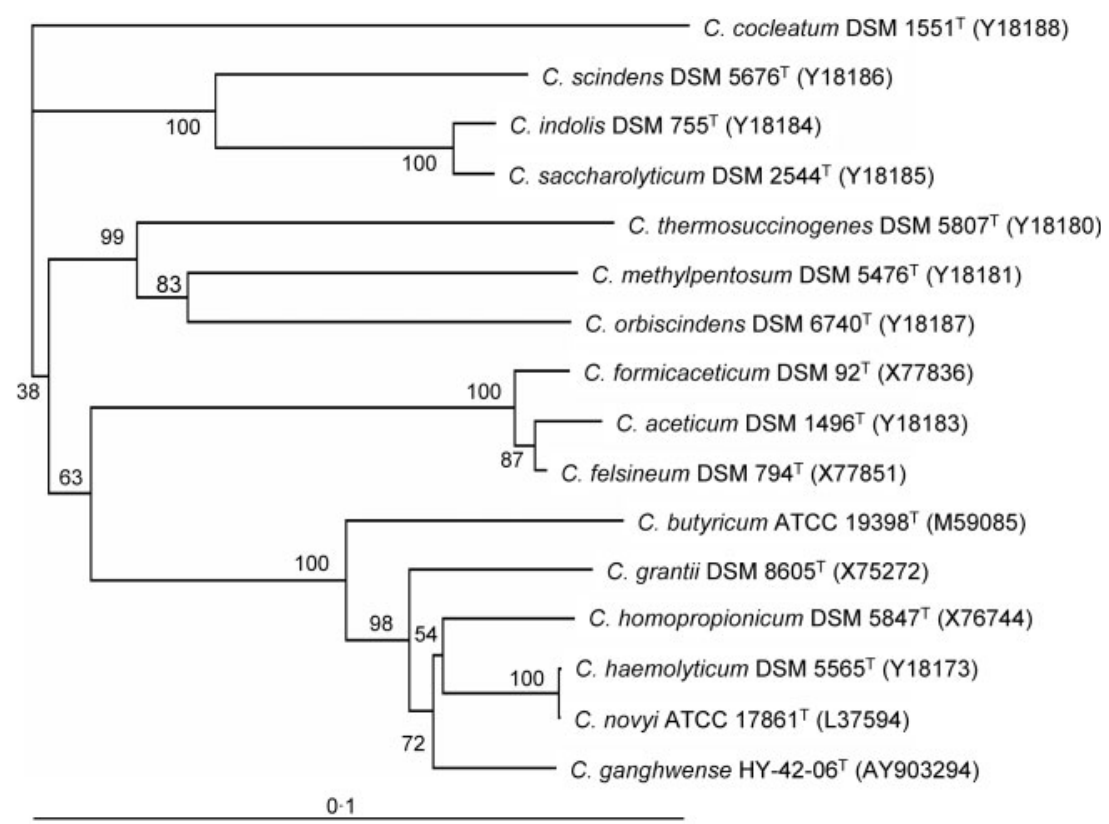

Fig. 1. Neighbour-joining tree based on nearly complete $16 \mathrm{~S}$ rRNA gene sequences showing relationships between strain HY-42$06^{\top}$ and members of the genus Clostridium. Percentages at nodes are levels of bootstrap support based on neighbour-joining analyses of 1000 resampled datasets. Clostridium cocleatum DSM $1551^{\top}$ was used as an outgroup. Bar, $0 \cdot 1$ nucleotide substitution per position.
Gram-reaction was determined using Gram-staining and the KOH test (Johnson et al., 1995; Powers, 1995). Morphology was observed for cells grown on RCM at $30^{\circ} \mathrm{C}$ using phasecontrast microscopy and scanning and transmission electron microscopy. The presence of catalase was determined by the addition of $3 \%(\mathrm{v} / \mathrm{v}) \mathrm{H}_{2} \mathrm{O}_{2}$ to a cell smear on standard microscope slides. The $\mathrm{pH}$, temperature and sea salt ranges for growth were determined using RCM in Hungate tubes. Growth was recorded by measuring $\mathrm{OD}_{600}$ using a turbidometer (Biolog). Biochemical tests were performed using the commercially available API 20A system (bioMérieux) according to the manufacturer's instructions.

For the detection of fermentation end-products, basal medium (Hernandez-Eugenio et al., 2002) was slightly modified to contain the following $\left(1^{-1}\right.$ distilled water): $1 \mathrm{~g}$ $\mathrm{NH}_{4} \mathrm{Cl}, 0.3 \mathrm{~g} \mathrm{~K}_{2} \mathrm{HPO}_{4}, 0.3 \mathrm{~g} \mathrm{KH}_{2} \mathrm{PO}_{4}, 30 \mathrm{~g}$ sea salts (Sigma), $0.5 \mathrm{~g}$ cysteine hydrochloride, $1 \mathrm{mg}$ resazurin (Sigma), $1 \mathrm{ml}$ trace mineral element solution (DSM medium 318) and $1 \mathrm{ml}$ vitamin solution (DSM medium 141). The final $\mathrm{pH}$ was adjusted to 7 with $10 \mathrm{M} \mathrm{KOH}$. After 2 weeks incubation at $30^{\circ} \mathrm{C}$, fermentation products were analysed using HPLC (HP1100; Hewlett Packard) equipped with an Aminex HPX-87H (Bio-Rad) column, refractory index detector and diode array detector $(210 \mathrm{~nm}) . \mathrm{H}_{2} \mathrm{SO}_{4}$

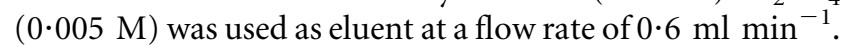
Carbon dioxide was analysed using GC (ACME6000GC; Young-lin) equipped with a Porapak Q (Supelco) column and thermal conductivity detector. Helium was used as the

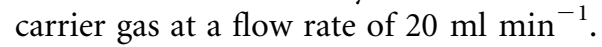

Cells were motile rods with peritrichous flagella (see Supplementary Figs S1 and S2 in IJSEM Online). The isolate required sea salts for growth and was unable to grow in the presence of $\mathrm{NaCl}$ alone. Detailed morphological, physiological and biochemical characteristics of strain HY- $42-06^{\mathrm{T}}$ are given in the species description and Table 1.

It is evident from Table 1 that several phenotypic characters readily separate strain HY- $42-06^{\mathrm{T}}$ from other phylogenetically related species, namely $C$. novyi, $C$. haemolyticum and $C$. homopropionicum. On the basis of the polyphasic evidence presented here, isolate HY- $42-06^{\mathrm{T}}$ represents a novel species in the genus Clostridium for which the name Clostridium ganghwense sp. nov. is proposed.

Table 1. Characteristics that differentiate strain $H Y-42-06^{\top}$ from phylogenetically related species

Strains: 1, Strain HY-42-06 ${ }^{\mathrm{T}}$; 2, Clostridium novyi ATCC $17861^{\mathrm{T}}$; 3, Clostridium haemolyticum DSM $5565^{\mathrm{T}}$; 4. Clostridium homopropionicum DSM $5847^{\mathrm{T}}$. Data are from this and earlier studies (Breed et al., 1957; Dorner \& Schink, 1990). +, Positive reaction; -, negative reaction; $\mathrm{V}$, variable; $\mathrm{ND}$, no data available.

\begin{tabular}{|lcccc|}
\hline Characteristic & $\mathbf{1}$ & $\mathbf{2}$ & $\mathbf{3}$ & $\mathbf{4}$ \\
\hline Gram-staining & - & + & + & - \\
Sea salts requirement & + & - & - & - \\
Indole production & + & - & + & $\mathrm{ND}$ \\
Utilization of: & & & & \\
$\quad$ Glucose & + & + & + & - \\
$\quad$ Glycerol & - & $\mathrm{V}$ & + & - \\
$\quad$ Maltose & + & $\mathrm{V}$ & - & $\mathrm{ND}$ \\
$\quad$ Salicin & + & - & - & $\mathrm{ND}$ \\
\hline
\end{tabular}




\section{Description of Clostridium ganghwense sp. nov.}

Clostridium ganghwense (gang.hwen'se. N.L. neut. adj. ganghwense named after Ganghwa Island in South Korea, the geographical origin of the type strain).

Strictly anaerobic, chemoheterotrophic, rod-shaped $(4-8 \mu \mathrm{m} \times 0 \cdot 7-0 \cdot 8 \mu \mathrm{m})$ and motile with peritrichous flagella. Cells are catalase-negative. Colonies are circular and yellowish on RCM. Requires 1-9\% (w/v) artificial sea salts (optimum $3 \%$ ). Does not grow on RCM containing $0-5 \%(\mathrm{w} / \mathrm{v}) \mathrm{NaCl}$ alone. The temperature range for growth is $15-40{ }^{\circ} \mathrm{C}$, optimum growth temperature is $35^{\circ} \mathrm{C}$. Optimum $\mathrm{pH}$ of RCM for growth is $7 \cdot 5$ and growth occurs between $\mathrm{pH} 5 \cdot 5$ and 10.0. The $\mathrm{KOH}$ reaction and Gramstaining are negative. Indole is produced and urease is absent. Gelatin and aesculin are hydrolysed. Glucose, maltose, salicin, cellobiose and mannose are utilized, but mannitol, lactose, sucrose, xylose, arabinose, glycerol, melezitose, raffinose, sorbitol, rhamnose and trehalose are not utilized. The fermentation end-products from glucose are glycerol, ethanol and $\mathrm{CO}_{2}$.

The type strain, HY-42-06 ${ }^{\mathrm{T}}\left(=\mathrm{IMSNU} 40127^{\mathrm{T}}=\mathrm{KCTC}\right.$ $5146^{\mathrm{T}}=$ JCM $13193^{\mathrm{T}}$ ), was isolated from tidal flat sediment of Ganghwa Island in South Korea.

\section{Acknowledgements}

This work was supported, in part, by the Korea Ministry of Science and Technology under National Research Laboratory Program (M10500000110-05J0000-11010), 21C Frontier Microbial Genomics and Applications Center Program (MG05-0101-2-0) and Korea Institute of Science and Technology.

\section{References}

Breed, R. S., Murray, E. G. D. \& Smith, N. R. (1957). Bergey's Manual of Determinative Bacteriology, 7th edn. Baltimore: Williams \& Wilkins.

Chun, J. S. \& Goodfellow, M. (1995). A phylogenetic analysis of the genus Nocardia with $16 \mathrm{~S}$ rRNA gene sequences. Int J Syst Bacteriol 45, 240-245.

Chun, J., Bae, K. S., Moon, E. Y., Jung, S. O., Lee, H. K. \& Kim, S. J. (2000). Nocardiopsis kunsanensis sp. nov., a moderately halophilic actinomycete isolated from a saltern. Int J Syst Evol Microbiol 50, 1909-1913.

Collins, M. D., Lawson, P. A., Willems, A., Cordoba, J. J., FernandezGarayzabal, J., Garcia, P., Cai, J., Hippe, H. \& Farrow, J. A. (1994).
The phylogeny of the genus Clostridium: proposal of five new genera and eleven new species combinations. Int J Syst Bacteriol 44, 812-826.

Dorner, C. \& Schink, B. (1990). Clostridium homopropionicum sp. nov., a new strict anaerobe growing with 2-, 3-, or 4hydroxybutyrate. Arch Microbiol 154, 342-348.

Felsenstein, J. (1985). Confidence limits on phylogenies: an approach using the bootstrap. Evolution 39, 783-791.

Felsenstein, J. (1993). PHYLIP (phylogenetic inference package), version 3.5.1. Distributed by the author. Department of Genome Sciences, University of Washington, Seattle, USA.

Fitch, W. M. (1971). Toward defining the course of evolution: minimum change for a specific tree topology. Syst Zool 20, 406-416.

Fitch, W. M. \& Margoliash, E. (1967). Construction of phylogenetic trees. Science 155, 279-284.

Hernandez-Eugenio, G., Fardeau, M. L., Cayol, J. L. A., Patel, B. K. C., Thomas, P., Macarie, H., Garcia, J. L. \& Ollivier, B. (2002). Clostridium thiosulfatireducens sp. nov., a proteolytic, thiosulfate- and sulfur-reducing bacterium isolated from an upflow anaerobic sludge blanket (UASB) reactor. Int J Syst Evol Microbiol 52, 1461-1468.

Jeon, Y.-S., Chung, H., Park, S., Hur, I., Lee, J.-H. \& Chun, J. (2005). jPHYDIT: a JAVA-based integrated environment for molecular phylogeny of ribosomal RNA sequences. Bioinformatics 21, 3171-3173.

Jeong, H., Yi, H., Sekiguchi, Y., Muramatsu, M., Kamagata, Y. \& Chun, J. (2004). Clostridium jejuense sp. nov., isolated from soil. Int J Syst Evol Microbiol 54, 1465-1468.

Johnson, M. J., Thatcher, E. \& Cox, M. E. (1995). Techniques for controlling variability in Gram staining of obligate anaerobes. J Clin Microbiol 33, 755-758.

Jukes, T. H. \& Cantor, C. R. (1969). Evolution of protein molecules. In Mammalian Protein Metabolism, pp. 21-132. Edited by H. N. Munro. New York: Academic Press.

Kim, B. S., Oh, H. M., Kang, H., Park, S. S. \& Chun, J. (2004). Remarkable bacterial diversity in the tidal flat sediment as revealed by $16 \mathrm{~S}$ rDNA analysis. J Microbiol Biotechnol 14, 205-211.

Powers, E. M. (1995). Efficacy of the Ryu nonstaining $\mathrm{KOH}$ technique for rapidly determining Gram reactions of food-borne and waterborne bacteria and yeasts. Appl Environ Microbiol 61, 3756-3758.

Saitou, N. \& Nei, M. (1987). The neighbor-joining method: a new method for reconstructing phylogenetic trees. Mol Biol Evol 4, 406-425.

Swofford, D. L. (1998). PAUP: Phylogenetic analysis using parsimony, version 4. Sunderland, MA: Sinauer Associates.

Yi, H. \& Chun, J. (2004). Nocardioides ganghwensis sp. nov., isolated from tidal flat sediment. Int J Syst Evol Microbiol 54, 1295-1299.

Yi, H., Chang, Y. H., Oh, H. W., Bae, K. S. \& Chun, J. (2003). Zooshikella ganghwensis gen. nov., sp. nov., isolated from tidal flat sediments. Int J Syst Evol Microbiol 53, 1013-1018. 